\title{
MOLLA SADRETTIN YÜKSEL VE TEFSIR ANLAYIŞI*
}

\section{Özet}

\section{Dr. Öğr. Üyesi Mehmet ALTIN**}

İslam medeniyeti kurulduğu günden beri inşa ettiği sayısız eğitim kurumlarında nice âlim ve bilgin şahsiyetler yetiştirmiştir. 20. Yüzyılda Cumhuriyet dönemi Türkiye'sinde yetişen âlimlerden birisi de Molla Sadrettin Yüksel'dir. 1920 yılında doğan Molla Sadrettin, aslen Bitlis'in Adilcevaz ilçesinden olup 11-12 yaşlarında Arapça tedrisata başlar. Norşin, Ohin ve Baykan'ın Havil köyünde okuyarak medrese eğitimini tamamlar ve Norşin medresesine dönüp orada ders vermeye başlar. 1958 yılında Siirt'in Baykan ilçesine müftü olarak atanır. Kısa bir müddet sonra bu görevden istifa eder ve tekrar Norşin medresesine döner. 1966 y1lında ailesiyle beraber İstanbul'a göç eder. İstanbul'a yerleştikten sonra 1996 yılına kadar ulum-i diniyye ile ilgili özel dersler verir. Türkçe, Arapça, Kürtçe ve Farsça bilen Molla Sadrettin 25 Aralık 2004 yılında vefat eder. Molla Sadrettin, farklı alanlarda bir kısmı yayımlanmış bir kısmı da hala yayımlanmamış Türkçe ve Arapça irili ufaklı 33 eser kaleme alır. Bu eserleri arasında Haşiye 'Ala Tefsiri İşârâti'l-İ'caz fî Mezani'l-İcâz ile Fatiha Sûresinin Meâli ve Tefsiri de vardır. Bu iki çalışma onun tefsir ilmindeki vukufiyetini ve tefsir anlayışını göstermesi açısından önemlidir. Biz bu makalemizde söz konusu âlimimiz Molla Sadrettin Yüksel'in hayatı ve ilmi kişiliği ile tefsir anlayıșını konu edineceğiz.

Anahtar Kelimeler: Tefsir, Kur'ân, Âlim, Medrese, Molla Sadrettin.

\section{MOLLA SADRETTIN YUKSEL AND HIS UNDERSTANDING OF TAFSIR}

\begin{abstract}
Since the day it was founded, Islamic civilization has raised many scholars and scholarly personalities in the numerous educational institutions it has established. Molla Sadrettin Yüksel is one of the scholars who grew up in the Republic period of Turkey in the 20th century. Molla Sadrettin, who was born in 1920, was originally from the Adilcevaz district of Bitlis and started teaching in Arabic at the age of 11-12. He completed his madrasa education by studying in the village of Havil of Norshin, Ohin and Baykan, and returned to the Madrasa of Norshin and began teaching there. In 1958, he was appointed as a mufti to the Baykan district of Siirt. After a short while, he resigned from this post and returned to the Norşin madrasah. He immigrated to Istanbul with his family in 1966. After settling in Istanbul, he gave private lessons on ulum-i diniyye until 1996. Molla Sadrettin, who knew Turkish, Arabic, Kurdish and Persian, passed away on 25 December 2004. Molla Sadrettin writes 33 large and small works in Turkish and Arabic, some of which have been published and some of which are still unpublished. Among these works are Haşiye 'Ala Tefsiri İşârâti'l-I'caz fî̀ Mezani'l-İcâz and the Translation and Interpretation of Fatiha Sûra. These two studies are important in terms of showing his knowledge of Tafsir and his understanding of tafsir. In this article, we will discuss the life and scientific personality of our scholar Molla Sadrettin Yüksel and his understanding of tafsir.
\end{abstract}

Keywords: Tafsir, Qur'an, Scholar, Madrasah, Molla Sadrettin.

\footnotetext{
* Bu makale 3-4 Haziran 2021 tarihinde Bitlis Eren Üniversitesi İslami İlimler Fakültesi’nin düzenlediği Uluslararası Bitlis ve Yöresi Manevi Mimarları Sempozyumu'nda sözlü olarak sunulan "Molla Sadrettin Yüksel ve Tefsir Anlayışı” isimli tebliğin gözden geçirilip yeniden düzenlenmiş halidir.

**Bitlis Eren Üniversitesi, İslami İlimler Fakültesi, Temel İslam Bilimleri Bölümü. e-mail: mehmet_altin13@hotmail.com ORCID: 0000-0003-4441-0821 Araştırma Makalesi Sayfa Sayıs1:1255-1273

Makale Geliş Tarihi:25.06.2021

Makale Kabul Tarihi:15.09.2021

Makale Yayın Tarihi:31.12.2021
} 


\section{Giriş}

(akademik, hakemli, indexli, uluslararası dergi)

Bitlis, binlerce yıllık bir geçmişi olan ve birçok medeniyete ev sahipliği yapmış bir şehirdir. İnsanlığın birçok ortak kültür mirasına sahip olan bu şehrimiz aynı zamanda İslam Medeniyetinin de önemli merkezleri arasında yer almaktadır. Müslümanlar tarafından fethedildikten sonra Bitlis, hem bir kültür şehri olmuş hem de medreseleriyle de hep ön planda olmayı başarmış ve günümüze kadar da bu özelliğini koruyabilmiştir. ${ }^{I}$ Çalışmalarımız sırasında Bitlis il merkezinde tespit ettiğimiz ve aralarında İdrisiye Medresesi, Şerefiye Medresesi, Şükriye Medresesi, Hamza Bey Medresesi, Hacı Bey Medresesi, Hatibiye Medresesi, İhlasiye Medresesi, Yusufiye Medresesi, Nuhiye Medresesinin de olduğu onlarca medresede zamanında ilmî faaliyetler gerçekleştirilmiştir. Diğger taraftan Bitlis, Hüsâmeddîn Ali el-Bitlisî, İdris-i Bitlisî, Şükrî-yi Bitlisî, Şeref Hân Bitlisî, Şems-i Bitlisî, Müştâk Baba, Şeyh Sibğatullah Arvâsî, Şeyh Abdurrahmân Tâğî, Şeyh Fethullah Verkânisî, Şeyh Muhammed Diyâüddîn, Şeyh Alâaddîn Ohinî, Said Nursî, Muhammed Küfrevî gibi yüzlerce âlim yetiştirmeyi başarabilmiştir.

Tarihten günümüze değin Bitlis, ilçe ve köylerinde ilim yuvaları olan söz konusu medrese kurumları devam etmiş 19. ve 20. yüzyılda özellikle Norşin ve Ohin gibi medreseler bu misyonu devam ettirerek günümüze kadar faaliyetlerini sürdürebilmiştir. Bilhassa Norşin medresesi, gerek yetiştirdiği önemli ilmî şahsiyetler, gerekse bölge halkı üzerindeki sosyal, dini ve kültürel etkileri bakımından haklı bir üne kavuşmuştur. ${ }^{2}$ Çalışmamıza konu olan Molla Sadrettin Yüksel'in hem Norşin medresesinde eğitiminin çoğunu almış olması hem de uzun yıllar bu medresede müderrislik yapmasından dolayı söz konusu medresenin kuruluşundan günümüze kadarki faaliyetlerinden kısaca bahsetmek isteriz.

Norşin medresesi Seyda lakabıyla meşhur Abdurrahman Tâğî (ö. 1886) tarafından kurulmuştur. Şeyh Sibğatullah Arvasî’nin (ö. 1870) halifesi Abdurrrahman Tâğî, İsparit nahiyesinde bulunan Tâğ Medresesi'nde müderrislik yapmaya devam ederken 1870 yılında şeyhi, vefat edince Hizan'ın Gayda köyüne gelir ve buradaki şeyhinin çocuklarına tekke ve irşad faaliyetlerinde yardımcı olur. Ancak bir süre sonra tekke ve irşad hizmetlerini şeyhinin oğlu Şeyh Celaleddin’e (ö. 1878) bırakarak takriben 1875 yılında Bitlis' in Norşin (Güroymak) nahiyesine yerleşir ve burada medrese ve tekkesini kurar. ${ }^{3}$ Abdurrrahman Tâğ̂̂, Norşin'deki etkili eğitim ve irşad alanındaki hizmetleri

\footnotetext{
${ }^{1}$ Mehmet İnbaşı - Mehmet Demirtaş (ed.), Tarihî ve Kültürel Yönleriyle Bitlis (Ankara: Kalkan Matbaacılık, 2019), 1/9. 2 İmran Çelik, "Geleneği Olan Medreseler ve Tarihi Kökenleri (Tillo Ve Nurşin Örnekleri)", Medrese Geleneği ve Modernleşme Sürecinde Medreseler Uluslararası Sempozyum, ed. Fikret Gedikli (Muş: Muş Alparslan Üniversitesi Yayınları, 2013), 1/105-106.

${ }^{3}$ Şefik Korkusuz, Nehrî'den Hazne'ye Meşayih-i Nakşibendî, (İstanbul: Pak Ajans Yayıncılık, 2010), 86-95; Mehmet Saki Çakır, "Şeyh Abdurrahman Tâğî ve Norşin Tekkesi’nden Yayılan Kollar", Ihyya Uluslararası Íslam Araştırmaları Dergisi 3/2 (Temmuz 2017), 30.
} 
... (akademik, hakemli, indexli, uluslararası dergi)

buranın bölgenin en önemli ilim ve irfan merkezi olmasını sağlar. Nitekim bu medreseden istifade edenlerden biri olan Said Nursî’nin (ö. 1960) daha sonra buradaki insanlar hakkında övünerek söylediği şu sözler bu durumu özetlemektedir: “...Eğer istersen hayalinle Norşin karyesindeki Seyda'nın (Abdurrahman Tâğ̂̀) meclisine git bak: Orada fukara klyafetinde melikler, padişahlar ve insan elbisesinde melâikeleri, bir sohbet-i kudsiyyede göreceksin. Sonra Paris'e git ve en büyük localarına gir. Göreceksin ki akrepler insan libası giymişler ve ifritler adam suretini almışlar ..."4

Şeyh Abdurrrahman Tâğî 1886 yılında vefat edinceye kadar ilim ve irşad hizmetlerini kesintisiz olarak devam ettirir. Vefatından sonra Norşin'de yerine bir müddet halifesi Şeyh Fethullah Verkânisî (ö. 1899) medrese ve tekke hizmetlerini yürütür. Ancak Verkânisî, Tâğî’nin oğlu Şeyh Muhammed Diyauddin (ö. 1924) icazet alınca medrese ve tekke hizmetlerini ona birakır. ${ }^{5}$ Norşin Medresesi bu dönemden itibaren bölgede en verimli, en kalabalık ve en kaliteli medrese tahsilinin yapıldığı merkezlerden biri haline gelir. ${ }^{6}$

Şeyh Muhammed Diyauddin'den sonra kardeşi Abdurrahim'in oğlu Şeyh Muhammed Masum (ö. 1971) medrese ve tekke hizmetleriyle meşgul olur. Şeyh Masum döneminde Norşin Medresesi en parlak dönemini yaşar. Norşin Medresesi bu dönemde özellikle halk arasındaki anlaşmazlıkların çözüm merci olur. ${ }^{7}$

1950 yılının sonlarına kadar tek bir medrese ve divan olarak din eğitimine hizmet eden Norşin Medresesi, bu tarihten sonra ilginin yoğunluğundan dolayı bölünmek zorunda kalır. Bu tarihten sonra Şeyh Masum ile Şeyh Takiyeddin (ö. 1967) Norşin'de talebe yetiştirmeye devam ederken, Şeyh Taha Muş'un Bulanık ilçesine bağlı Günbatmaz (Adgon) köyünde, Şeyh Nasır ise Bitlis Demirci köyünde medrese kurarak talebe yetiştirmeye başlarlar. Şeyh Taha ve Şeyh Nasır'ın çocukları daha sonra 1970'li yılların başlarında Norşin'de de medrese kurarlar. Şeyh Masum tarafından devam ettirilen medrese, Şeyh Masum'un vefatından sonra Şeyh Muhammed Maşuk (ö. 1975) tarafından idare edilir.

Günümüzde Şeyh Masum kanalıyla gelen medrese hizmetlerini Şeyh Nurettin yürütmekte idi. Ancak Covid-19 hastalığı sebebiyle 10 Aralık 2020 tarihinde vefat edince medrese ve divan hizmetlerini oğlu Abdülgani Mutlu üstlenmiş bulunmaktadır. Şeyh Takyeddin kanalıyla gelen medrese geleneğini Şeyh Muhammed Hafit Efendi Medresesi ismiyle Şeyh Abdülkerim Çevik

\footnotetext{
${ }^{4}$ Said Nursî, Mesnevî-i Nuriye (İstanbul: Envar Neşriyat, 1995), 263.

${ }^{5}$ Çakır, "Şeyh Abdurrahman Tâğî ve Norşin Tekkesi’nden Yayılan Kollar", 31.

${ }^{6}$ M. Halil Çiçek, Şark Medreselerinin Serencamı (İstanbul: Beyan Yayınları, 2009), 158.

${ }^{7}$ Metin Ermiş, Hâlidî Medrese Geleneği ve Norşin Medresesi (Van: Van Yüzüncü Yıl Üniversitesi, Sosyal Bilimler Enstitüsü, Yüksek Lisans Tezi, 2019), 24.

${ }^{8}$ Ermiş, Hâlidî Medrese Geleneği ve Norşin Medresesi, 40-41.
} 
... (akademik, hakemli, indexli, uluslararası dergi)

tarafindan devam ettirilirken 19 Ocak 2020 tarihinde medresede öğrencilere ders verdiği esnada uğradığı silahlı saldırı sonucunda hayatını kaybetmiştir. Şeyh Nasır tarikiyle sürdürülen medrese Şeyh Fadli tarafından devam ettirilmiş onun da vefatıyla oğlu Şeyh Alameddin hâlihazırda medrese hizmetini sürdürmektedir. Şeyh Taha tarafından Bulanık Günbatmaz (Adgon) köyünde kurduğu medrese hizmetleri halen torunları tarafindan sürdürülmektedir. ${ }^{9}$

Kurulduğu günden günümüze Norşin medrese ekolü binlerce talebe yetiştirmiştir. $\mathrm{Bu}$ medresede az veya çok kalarak istifade etmiş birçok şahsiyetten bazılarını şu şekilde sıralayabiliriz: Said Nursî, Şefik Arvasî, Halil Gönenç, Şeyh Alaaddin Ohinî, Şeyh Asım Ohinî, Mehmet Emin Er, Ali Arslan, Molla Muhammed Şirin, Mehmet Çağlayan, Abdulkerim Saruhan, Molla Burhan Mucahidi. ${ }^{10}$

Norşin medresesinin yetiştirmiş olduğu âlimlerden biri de Molla Sadrettin Yüksel'dir. Biz bu çalışmada evvela Molla Sadrettin Yüksel'in hayatı ve ilmi kişiliğini inceleyecek sonra da tefsir anlayışını ortaya koymaya çalışacağız.

\section{Molla Sadrettin Yüksel’in Hayatı, İlmi Kişiliği ve Eserleri}

\subsection{Ailesi, Doğumu ve Evliliği}

Sadreddin Yüksel aslen Bitlis’in Adilcevaz ilçesinin Erikbağı (Koçeri) köyünden olup ailesi Kürtlerin Haydaran aşiretinden gelmektedir. Babası Tahir Efendi (ö. 1927), annesi ise Hatun Hanım (ö. 1985)'dır. Birinci Dünya Savaşı'nda Rusların Ermenilerle birlikte Adilcevaz ve çevresine saldırmasından dolayı Tahir Efendi bir kısım akrabalarıyla beraber Konya’nın Sarayönü ilçesine göç etmek zorunda kalırlar. ${ }^{11}$ Sadrettin Yüksel, 1920 yılında Sarayönü ilçesinde dünyaya gelir. Mütareke döneminin ardından Tahir Efendi ailesini alarak Konya'dan Koçeri köyüne tekrar döner. Yüksel henüz yedi yaşında iken babası hastalanarak Adilcevaz’ın Göldüzü (Arin) köyünde genç yaşta vefat eder. $^{12}$

Molla Sadrettin küçük yaştan itibaren Bitlis ve çevre illerde bulunan bazı medreselerde tahsil gördükten sonra 1951 yılında Şeyh Masum’un kızı Sarete ile evlenir. 1955 yılında İzmir Menemen ilçesinde başladığı askerliğini Ankara'da tamamlar. 1958 yılında Ankara'da girmiş olduğu müftülük sınavında birinci olur ve Siirt'in Baykan ilçesine müftü olarak atanır. Fakat kısa bir süre sonra Norşin

\footnotetext{
${ }^{9}$ Geniş bilgi için bk. İzzettin Ürek, Günümüz Bitlis Medreselerinde Mantık Eğitimi (Norşin Medreseleri Örneği), (Diyarbakır: Dicle Üniversitesi, Sosyal Bilimler Enstitüsü, Yüksek Lisans Tezi, 2020), 32-35.

10 İbrahim Baz, “Osmanlı'dan Cumhuriyete Norşin Dergâhı ve Şeyh Abdurrahman-1 Tâğ̂̂”, Tasavvuf /34 (Temmuz-Aralık 2014), 99-100.

${ }^{11}$ Müfid Yüksel, “Sadrettin Yüksel Hocanın Ardından”, Tezkire /41 (Kasım-Aralık-Ocak 2005), 202.

${ }^{12}$ Müfid Yüksel, "Sadreddin Yüksel”, Hadis Tetkikleri Dergisi 3/1 (Haziran 2005), 195-196.
} 
... (akademik, hakemli, indexli, uluslararası dergi)

medresesinde ders vermek üzere bu görevi bırakır. 1960 yılında ise fahri imamlık yapmak üzere Muş’un Bulanık ilçesinin Uzgörür (Neynik) köyüne taşınır. ${ }^{13} 1966$ yılında ailesini alarak İstanbul'a taşınır ve bazı özel kurslarda Arapça ve İslami ilimler okutur. 1968 yılında ise Diyanet İşleri Başkanlığınca İstanbul Merkez vaizliğine atanır. Bu görevini sürdürürken 1975 yılında İstanbul müftüsü Abdurrahman Şeref Güzelyazıcı'nın kendisine olumsuz bir tavır takınmasından dolayı görevinden istifa etmek zorunda kalır. Molla Sadrettin, Metin, Edip, Müfid ve Nedim dahil yedi çocuk babasıdır. 25 Aralık 2004 yılında bir Cumartesi günü sabah saat 10:30 civarında evinde vefat eder ve Edirnekapı Mezarlı̆̆ı'na defnedilir. ${ }^{14}$

\section{2. İlmî Hayatı}

Molla Sadrettin Yüksel, babasının vefatından sonra daha 11-12 yaşlarında iken okumak üzere ailesinden ayrılır. Kur'ân-1 Kerim'i hatmettikten sonra Muş’un Bulanık ilçesinin Oğlakkaya (Purkaşin) köyünde Molla Zübeyr'in yanında sarf-nahiv okur. Sonra Elçiler (Resulan) ve Dokuzpınar (Koğak) köylerinde tahsiline devam eder. 1934 yılında bölgenin en büyük ilim merkezi kabul edilen Bitlis Norşin'de bulunan Şeyh Abdurrahman Tâğî'nin medresesine gider. Bu sırada medresenin başında Tâğî’nin torunu Şeyh Masum bulunur. Sadrettin Yüksel, bu medresede Şeyh Takiyuddin ve Molla Abdülbaki'nin (ö. 1972) yanında okur. ${ }^{15}$

Daha sonra Molla Sadrettin Yüksel, Mutki'nin Yukarı Koyunlu (Ohin) köyündeki medreseye giderek, burada Şeyh Fethullah Verkanisî’nin oğlu Şeyh Alauddin (ö. 1949) ve onun oğlu Şeyh Mazhar'ın (ö. 1988) yanında tedrisatına devam eder. Bu medresede eğitimini devam ettirirken Şeyh Alauddin'den el alarak Nakşibendi tarikatına intisab eder. Daha sonra Baykan ilçesinin Havili köyüne giderek Molla Muhyiddin Havilî’nin (ö. 1988) yanında medrese eğitimine devam eder ve tedrisatını burada tamamlar. Bundan sonra Norşin'e döner ve burada ders vermeye başlar. 1947 yılında Molla Sadrettin, Şeyh Maşuk ile beraber Suriye'de yaşayan Şeyh Ahmed el-Haznevî’yi (ö. 1950) ziyaret eder. O sırada Şam'da bulunan Şeyh Muhammed İsa'nın (ö. 1997) isteğiyle Şam’a gidip yerleşmek istese de Şeyh Masum gitmesini istemediğinden vazgeçerek Norşin'de medresede ders vermeye devam eder. 1945 yılında Bediüzzaman Said Nursî̀yle tanışıp mektuplaşmaya başlar. ${ }^{16} 1952$ yılında birkaç kez bizzat Emirdağ'da kendisini ziyaret eder. 1958 yılında Bediüzzaman'ın isteğiyle İşaratü’li'câz tefsirini yayıma hazırlayıp bir takriz ile birlikte Ankara' da yayımlar. ${ }^{17}$

\footnotetext{
13 Yüksel, "Sadrettin Yüksel Hocanın Ardından”, 204-207.

14 Yüksel, "Sadrettin Yüksel Hocanın Ardından”, 204-207.

15 Yüksel, "Sadreddin Yüksel”, 196.

${ }^{16}$ Bk. Ek: 3

17 Yüksel, "Sadrettin Yüksel Hocanın Ardından", 204-207.
} 
Molla Sadrettin Yüksel, 1964 yılında Diyanet İşleri Başkanlığı tarafından Kur’ân-1 Kerim meâl ve tefsirini hazırlamakla görevlendirilir, ancak bu proje sonradan yarım kalır. İstanbul'a taşındıktan sonra Sultan Ahmed Camii imamı Gönenli Mehmed Efendi’nin (ö. 1991) kurslarında ve İsmail Ağa Kurs'unda talebelere Arapça ve İslami ilimleri okutur. İstanbul merkez vaizliği görevini sürdürürken Yüksek İslam Enstitüsü öğrencilerine özel dersler verir. Genelde sarf-nahiv dersleri başta olmak üzere usûl, fikıh, tefsir, kelam, siyer ve mantık derslerini okutur. Bunların yanı sıra Mevlâna Celâleddîn-i Rumî'nin Mesnevisi, Sa'di'nin Gülistan'1, Molla Cami'nin Divân'1 ve Baharistan'1, Mevlâna Halidi Bağdadî'nin Divân'1, Birgivî'nin Tarikat-1 Muhammediye'si, Bediüzzaman'ın İşârâtü'l-i'câz'1, Mesnevî-i Nuriye'si ve Kızıl İcâz’1 gibi eserleri de okutur. Molla Sadrettin Yüksel, İslami ilimlere vukufiyeti yanında dil kabiliyeti de üst düzeyde olup Türkçe, Kürtçe, Arapça ve Farsça dillerini iyi derecede bilmekteydi. ${ }^{18}$

\section{3. İlmi Kişiliği ve Eserleri}

Molla Sadrettin Yüksel bölgenin en etkili medreselerinden olan başta Norşin ve Ohin olmak üzere değişik medreselerde köklü bir Arapça ve İslami ilimler tahsilini görmüş, keskin zekâsı ve azmi sayesinde dikkatleri üzerine çekebilmiş ve kısa sürede çevresinde ilmî kişiliğiyle tanınmıştır. Molla Sadrettin ibarelerin sathi manalarıyla yetinmeyip derinlemesine tahkik eden, okuduğunu eleştirisel bir gözle inceleyip gerektiğinde birkaç nüshayı karşılaştıran bir âlimdir. ${ }^{19}$ Diğer taraftan Molla Sadrettin, bazen okuduğu matbu bir kitabın basılmış olanıyla iktifa etmeyip gerek gördüğü yerleri el yazma nüshalarıyla karşılaştıran, okuduğu bir tercümeyi gerekli gördüğünde aslıyla karşılaştıran bir muhakkiktir. İşte bu muhakkikliği ve müdekkikliği Yüksel'de bir özgüven duygusunu oluşturmuş, mütevazı bir ahlaka sahip olmakla beraber yeri geldiğinde kendisi için "İslam âlimi”" veya "İslami konularda yetkili bir kimse" tabirini kullanabilmiştir. ${ }^{20}$

Molla Sadrettin Yüksel, yaşadığg dönemde ortaya çıkan çağdaş problemlere kayıtsız kalmamış yerinde açıklamaları ve İslami kaynaklardan aktardığı hükümlerle önemli meselelere 1şık tutmuştur. Yüksel'in İslami hükümleri cesaretle söyleyebilmesi ve fikhî bilgisini son derece pratik olarak kullanabilmesi insanların kendisine yoğun bir şekilde fetva sormasına neden olmuştur. ${ }^{21}$

Molla Sadrettin Yüksel'in diğer bir özelliği, bir taraftan ilmî çalışmalarla iştigal ederken diğer taraftan kimden ve/veya hangi kurumdan gelirse gelsin, yanlış bulduğu fikir ve fetvalarla şiddetle

\footnotetext{
18 Yüksel, “Sadreddin Yüksel”, 197; Yüksel, “Sadrettin Yüksel Hocanın Ardından”, 208.

${ }^{19}$ Mehmet Sadık Elçi, Son Dönem Âlimlerden Molla Sadrettin Yüksel ve Fetvâları (Diyarbakır: Dicle Üniversitesi, Sosyal Bilimler Enstitüsü, Yüksek Lisans Tezi, 2010), 8.

${ }^{20}$ Elçi, Son Dönem Âlimlerden Molla Sadrettin Yüksel ve Fetvâları, 10.

${ }^{21}$ Sadrettin Yüksel, İslamî Araştırmlar (İstanbul: Madve Yayınları, 1992), 6.
} 
... (akademik, hakemli, indexli, uluslararası dergi)

mücadele etmiş ve reddiyeler yazmıştır. ${ }^{22}$ Sadece şahıslar değil mesela Diyanet İşleri Başkanlı̆gı ve

Din İşleri Yüksek Kurulu gibi bazı kurum ve kurullar da Molla Sadrettin'in eleştirilerine hedef olabilmiştir. $^{23}$

Molla Sadrettin Yüksel, farklı alanlarda bir kısmı yayımlanmış bir kısmı da hala yayımlanmamış Türkçe ve Arapça irili ufaklı 33 eser kaleme almıştır. Bir kısmını şöylece sıralayabiliriz: ${ }^{24}$

1. Prof. Muhammed Hamidullah'ın İslâm Peygamberi ve Muhammed Resulullah Adlı Eserlerine Reddiye, Fazilet Neşriyat, İstanbul, 1975.

2. Mevlâna Halid-i Bağdâdî’nin Divanı ve Şerhi, Sabah Kültür Yayınları, İstanbul, 1977.

3. İslâmî Araştırmalar, Tûba Yayınları, İstanbul, 1982.

4. İslâmî Açıdan Lâiklik, Tahran, 1983.

5. Makaleler-I, Madve Yayınları, İstanbul, 1985.

6. Makaleler-II, Madve Yayınları, İstanbul, 1987.

7. Günümüz Meselelerine Kur'ân'dan Cevaplar, Makaleler-III, Madve Yayınları, İstanbul, 1988.

8. Makaleler-IV, Madve Yayınları, İstanbul, 1990.

9. İslamî Araştırmalar, Madve Yayınları, İstanbul, 1992.

10. Makaleler-V, Madve Yayınları, İstanbul, 1993.

Arapça eserleri:

1. Şerhu'l-Elğâz, Şamil Yayınevi, İstanbul, 1983.

2. Risâletun fi Şe'ni’l-Cum'ati, İstanbul, 1983.

3. Haşiyetu 'ala Şarhi's-Sudûr fi Şerhi Hâli'l-Mevta fi'l-Kubûr, Kahraman Yayınları, İstanbul, 1985.

4. Haşiye 'ala Tefsiri İşârâti'l-İ'caz fi Mezani'l-İcâz, Med-Zehra Yayınları, İstanbul, 1988.

5. Şerhu İsagoci, Tebliğ Yayınları, İstanbul, 1988.

6. Tahkîk ve Haşiya 'ala Mecelleti’l-Ahkâmi’l-'Adliyye (Yayımlanmamıştır)

7. Haşiyetu 'ala Divâni İbn Fârid (Yayımlanmamıştır)

8. Ta'likât 'ala Haşiyeti Kızıl İcâz fi 'Illmi’l-Mantik (Müfid Yüksel tarafından yayıma hazırlanmış olup, yayımlanma aşamasındadır.)

Makalelerinin Yayımlandığı Gazeteler:

\footnotetext{
22 Örneğin Muhammed Hamidullah'a yazdığı reddiye için bk. Sadreddin Yüksel, Prof. Muhammed Hamidullah'ın İslâm Peygamberi ve Muhammed Resulullah Adlı Eserlerine Reddiye (Fazilet Neşriyat, İstanbul, 1975)

${ }^{23}$ Elçi, Son Dönem Âlimlerden Molla Sadrettin Yüksel ve Fetvâlarl, 11-12.

${ }^{24}$ Bk. Yüksel, "Sadrettin Yüksel Hocanın Ardından", 208-209.
} 
1. Yeni İstiklâl (Haftalık Gazete, 1961-66 yılları arasında Mehmed Şevket Eygi Tarafından yayımlanmıştır.)

2. Bugün (Günlük Gazete, 1966-1971 yılları arasında yayımlanmıştır.)

3. Sabah (Günlük Gazete, 1981 yılına kadar yayınını sürdürmüştür.)

4. Ufuk (Haftalık Gazete)

5. Büyük Gazete (Haftalık, 1976-1980 yılları arasında Mehmet Şevket Eygi tarafindan yayımlanmıştır.)

6. Yeni Asya (Günlük Gazete)

7. Millî Gazete (Günlük Gazete)

Aylik Dergiler:

1. Hilâl (Salih Özcan Tarafından çıkarılan aylık dergi.)

2. İmza (1989-1994 yılları arasında yayımlanmıştır.)

\section{Molla Sadrettin Yüksel'in Tefsir Anlayışı}

Molla Sadrettin Yüksel, Arapça ve İslami ilimlerin hemen hemen her dalında mütehassıs ve söz sahibi birisidir. Ancak tedrisatı ve çalışmalarına bakıldığında daha çok tefsir alanına önem verdiği görülmektedir. Hâlihazırda Norşin medresesinin baş müderrisi olan Şeyh Abdülgani Mutlu'yla yaptığımız görüşmede Yüksel'in tefsir ilmine olan özel ilgisini bize şöyle anlatmıştır: "Molla Sadrettin, Norşin medresesinde müderrislik yaparken başta Beydâvî tefsiri olmak üzeri birçok tefsiri hem okur hem de okuturdu. Onun başka ilginç bir tarafı da medreselerimizde fazla okunmayan Arap alfabesindeki noktasız harfler kullanılarak yazılan mühmel tefsirlere ${ }^{25}$ olan özel ilgisiydi. Müellifini bilmediğim mühmel bir tefsiri sürekli mütalaa ettiğini hatırlıyorum." ${ }^{26}$ Molla Sadrettin Yüksel'in uzun yıllar Bediüzzaman Said Nursî'nin İşârâtü'l-i'câz’ını okutması da aynı şekilde Yüksel'in tefsir ilmine ayrı bir önem verdiğini göstermektedir. 1972-1974 yıllarında bu derslere katılan Edip Yılmaz, ${ }^{27}$ yaptığımız mülakatta Yüksel'in ders işleyiş biçimini bize şöyle aktarmıştır: "Molla Sadrettin Yüksel hocamızın o dönem her hafta Pazar günü Fatih Camii Kütüphanesi’nde Yüksek İslam Enstitüsü öğrencilerine yönelik verdiği İşârâtü'l-i'câz derslerine bir yıl boyunca katıldım. Hoca efendi, İşârâtü'l-i'câz'da işleyeceği dersi önce okur, sonra tercüme eder ve daha sonra genişçe tahlilini yapardı. Talebelerin birçoğu dersleri ses bantlarına kayıt ederdi. Nitekim ben de işlediğimiz

\footnotetext{
${ }^{25}$ Mühmel tefsir ile ilgili geniş bilgi için bk. Mehmet Altın, "Mühmel Tefsirler Üzerine Bir Değerlendirme”, Diyanet İlmi Dergi 56/3 (Eylül 2020), 653-676.

${ }^{26}$ Abdülgani Mutlu, Kişisel Görüşme (10.05.2021).

${ }^{27}$ Edip Yılmaz halen Bitlis Üniversitesi İslami İlimler Fakültesi’nde Dr. Öğr. Üyesi olarak çalışmaktadır.
} 
... (akademik, hakemli, indexli, uluslararası dergi)

derslerin birçoğunu ses bantlarında kayıt altına aldım ve hala da yanımda muhafaza etmekteyım.

Ayrıca Diyanet İşleri Başkanlığı tarafından Kur’ân-1 Kerim meâl ve tefsirini hazırlamakla görevlendirilmesi Molla Sadrettin Yüksel'in tefsir alanındaki yeterlilik ve yetkinliğini ifade etmektedir.

Molla Sadrettin Yüksel'in tefsir anlayışını irdelemeden önce tefsir alanında yaptığı çalışmalarına kısaca değinmekte yarar vardır. Bu çalışmaların bazıları aşağıdaki gibidir.

1. Haşiye 'ala Tefsiri İşârâti'l-İ'câz fî Mezani'1-İcâz: Molla Sadrettin Yüksel daha öncede ifade ettiğimiz gibi 1945 yılında Bediüzzaman Said Nursî’yle tanışıp mektuplaşmaya başlar ve kendisini birkaç kez ziyaret eder. Bediüzzaman kendisinden İşârâtü’l-i ‘câz’ı yayıma hazırlamasını ister. ${ }^{29} \mathrm{O}$ da söz konusu eseri 1918 yılında basılan nüshasını esas alarak 1959 yılında bir takrizle yayıma hazırlar. Molla Sadrettin, İşârâtü'l-i ‘câz'1 yayıma hazırlarken sayfa kenarında kimi yerlerde kendi el yazısı ile haşiyeler düşer. Metin içinde bulunan matbaa hatalarını tashih eder ve kimi kelimelere hareke verir. ${ }^{30}$ Daha sonra Med-Zehra yayınları Molla Sadrettin'in hem bu çalışmasını hem de İşarâtü'l-i'câz'1 talebelere okuturken yapmış olduğu düzeltme, gerekli ta'lik ve haşiyelerini dikkate alarak 1988 yılında Haşiye 'Ala Tefsiri İşârâti'l-İ'caz fî Mezani'l-İcâz adıyla yayımlar.

2. Fâtiha Sûresi Meâl ve Tefsiri: Molla Sadrettin Yüksel ve Fetvâları adında bir Yüksek Lisans çalışmasını yapmış olan Mehmet Sadık Elçi aracılığıyla temin etmiş olduğumuz bu çalışma; Yüksel'in kendi el yazısıyla kaleme aldığı müsvedde halinde 20 sayfadan müteşekkil bir çalışmadır. Molla Sadrettin bu çalışmasında farklı tefsirlerden istifade ederek Fâtiha sûresini Arapça olarak tefsir etmiş ve açıklamalı bir Türkçe meâl ilave etmiştir. Bu çalışmasında daha çok Beydâvî Tefsiri ve haşiyelerinden yararlanmıştır. Bunun yanında Râzî Tefsiri, Ebüssuûd Tefsiri, Fî zılâli'l-Kur'ân ve İşârâtü'l-i ‘câz gibi tefsirlerden de istifade ettiğini görmekteyiz. Yüksel'in Fâtiha sûresine yaptığı meâl ve çevirisi incelendiğinde açıklamalı ve daha çok bir tefsir görünümünü arz eden bir tarzda olduğu görülür. Birçok yerde dipnotlarla geniş açıklamalar yapmıştır. ${ }^{31}$

3. Günümüz Meselelerine Kur'ân'dan Cevaplar: 90 sayfalık bir eser olup 1988 yılında Madve Yayınları tarafından basılmıştır. Bu eserinde güncel bazı konuları Kur'ân perspektifinden değerlendirmektedir.

Molla Sadrettin Yüksel'in yukarıdaki çalışmaları çerçevesinde takip ettiği tefsir metodu ve tefsir anlayışını şu şekilde ortaya koymak mümkündür.

\footnotetext{
${ }^{28}$ Edip Y1lmaz, Kişisel Görüşme (15.05.2021).

${ }^{29}$ Yüksel, "Sadrettin Yüksel Hocanın Ardından”, 204-207.

${ }^{30}$ Bk. Said Nursî, İşârâtü’'l-i 'câz, (Ankara: DİB Yayınları, 2014), 62.

${ }^{31}$ Örnek için bk. Ek: 1; Ek: 2.
} 
a. Âyeti Hadisle Tefsir Etmesi: Molla Sadrettin Yüksel, âyetlerin izahı için genellikle Hz.

Peygamber'in sünnetine müracaat etmiş ve Resulullah'ın açıklamaları doğrultusunda âyetleri tefsir etmeye çalışmıştır. Hatta Kur'ân'1 tefsir edip de Hz. Peygambere ve hadislerine hiç yer vermeyen oğlu Edip ve benzerlerini sert bir dille eleştirerek şöyle der: "Böyle bir anlayış İslam peygamberine karşı korkunç bir cinâyettir. Sanki Allah tarafından Hz. Peygamber'e Kur'ân’ın manalarını beyan etme yetkisi verilmemiştir. Ne biçim ilim ve ne biçim iman! Oysaki o yetki ve selahiyet Cenab-1 Hak tarafindan son derece açık bir biçimde Nahl sûresinin 44. âyet ile Hz. Peygamber'e verilmiştir:”32 “İnsanlara indirdiklerimizi kendilerine açıklaman için ve (ola ki üzerinde) düşünürler diye sana da uyarıc kitabı indirdik. ",33

Yüksel, çalışmalarında âyetleri genellikle hadislerle tefsir eder. Bu âyetlerden biri de hırsızın

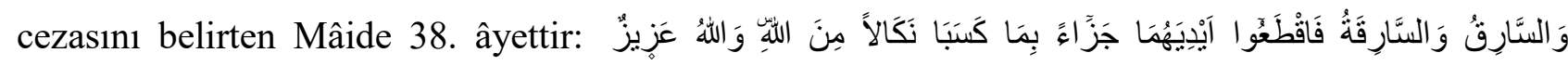

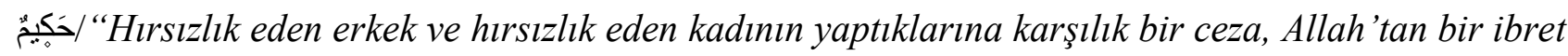
olarak ellerini kesin. Allah güçlüdür, hikmet sahibidir.",

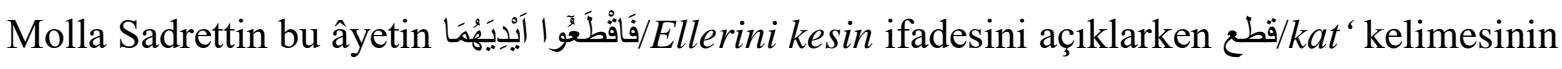
'kesip ayırmak' manasında olduğunu belirtir ve bu konuda birkaç sahih hadisin olduğunu söyler. Bir tanesini şöyle zikreder: “Efendimize bir hırsız getirildi, eli kesildi. Sonra Rasulullah'ın emriyle ibret olsun diye kesilen el, onun boynuna asıld1." 34 Yüksel'e göre bu hadis söz konusu kelimenin gerçek manasını ortaya koymaktadır. Ayrıca Molla Sadrettin âyette geçen 'el' kelimesinin mutlak bir ifade olduğunu belirtir ve şöyle der:

"El kelimesi lügat bakımından bileğe, dirseğe hatta omuza kadar da itlak edilir. Fakat burada -el kesme mevzuunda- peygamberin ve sahabeyi kiramın tatbikatları gayet açık bir şekilde sadece bileğe kadar murat olduğunu göstermektedir. Zira peygamberin emriyle hırsızın eli bilekten kesilmiştir. Bu konuda bir sürü hadis rivâyetleri de vaki olmuştur". ${ }^{35}$

b. Nüzul Bilgilerine Yer Vermesi: Molla Sadrettin, Fâtiha sûresini açılarken sûrenin nüzulüyle ilgili bilgiler verir. Fatiha sûresine es-seb 'u’l-mesânî denilmesinin bir sebebinin de nüzulünün tekrarlanması olduğunu belirtir ve şöyle der: "Fâtiha sûresi hem Mekke'de hem de Medine'de olmak üzere iki defa nâzil olmuştur. Mekke'deki nüzulü namaz farz kılındığında, Medine'deki nüzulü ise kıblenin tahvili esnasında gerçekleşmiştir." ${ }^{36}$

\footnotetext{
${ }^{32}$ Sadrettin Yüksel, Günümüz Meselelerine Kur'an'dan Cevaplar, (İstanbul: Madve Yayınları, 1988), 65.

${ }^{33}$ Nahl $16 / 44$.

${ }^{34}$ Bk. Ebû Îsâ Muhammed b. Îsâ b. Sevre et-Tirmizî, el-Câmi 'u's-sahîh, thk. Muhammed Nasruddin el-Elbânî, (Riyad: Mektebetü'l-Maarif, 2000), "Hudûd", 17 (No. 1473).

${ }^{35}$ Sadrettin Yüksel, Günümüz Meselelerine Kur'an'dan Cevaplar, (İstanbul: Madve Yayınlar1, 1988), 31-33.

${ }^{36}$ Sadrettin Yüksel, Fatiha Sûresi Meâl ve Tefsiri (Musvedde El Yazması), v1.
} 
-. (akademik, hakemli, indexli, uluslararası dergi)

c. Lügavî Tahliller Yapması: Hemen hemen bütün müfessirler kelime ve cümlelerin anlamları üstünde durdukları gibi, Molla Sadrettin Yüksel de lügavî tahlillere önem vermiştir. Mesela “Allah” lafz-i celâli tahlil ederken aslının ilah olup آََ/e-le-he kökünden geldiği ve mabud-u bi'l-hak olan Allah için kullanıldığını söyler. Aynı şekilde Taha 20/88. âyette geçen فَخْرَجَ لَهُمْ عِجْلاً جَسَداً لَلَهُ خُوَارٌ ifadesini "Derken onlara bögürrebilen bez, tahta ya da deriden bir buzağı heykeli yaptı" șeklinde anlayıp $^{37}$ bu buzağının cansız bir heykel olduğu iddiasında olanlara Yüksel جَسَّْ ve velimelerine yüklediği anlam üzerinden cevap verir ve der ki: "Söz konusu buzağı cansız bir heykel değildir. Zira kelimesi çoğunlukla et ve kemikten müteşekkil bedene itlak edilir. عَنَدْ de Arap lügatinde heykel değil buzağı manasına gelir. Durum böyle olduktan sonra nasıl bez, tahta ya da deriden yapılmış bir heykel olduğu söylenebilir." ${ }^{38}$ Aslında Molla Sadrettin burada, Sâmirî tarafindan oluşturulan buzağının et ve kemikten bir buzağı olduğu görüşünde olan el-Hasan, Katade, es-Süddî gibi âlimlerin görüşünü ${ }^{39}$ kabul etmekte ve bunu nakletmektedir. Ancak bu buzağı heykelinin ete, kemiğe büründürerek canlı saymak, Allah dışındaki mahluklara canlıyı yaratma sıfatını vermek gibi izahı mümkün olmayacak bir tartışma alanını açtığını/açabileceğini de ifade etmek gerekir.

d. İsrailiyyata Karşı Tutumu: Molla Sadrettin Yüksel'in ve tefsir çalışmalarına bakıldığında israiliyyata müracaat etmediği hatta tefsirlerde zikredilen bazı israiliyyat rivâyetlerini çok sert bir dille eleştirdiği görülecektir. Açıkçası bu, israiliyyata karşı kayda değer bir tavır koymadır. Dolayısıyla Yüksel'in bu tavrına bakarak, israiliyyata karşı olduğu ve Kur'ân'ı tefsir etmede bu tür rivâyetlere müracaat etmeye gerek olmadığı görüşünün taraftarı olduğunu söyleyebiliriz. Mesela Hz. Peygamber'in Zeyneb'le evlenmesi konusunun ele alındığı Ahzab 37. âyetin tefsirini yaparken bazı müfessirlerin israilliyata ve din düşmanları tarafından dine sokulan uydurmalara aldanıp hataya düştüklerini belirtir ve şöyle der: "Sözde Rasulullah, Zeyneb’i görmüş son derece ona vurulmuş. Bu ise öyle bir şeydir ki değil insanların en şereflisi olan Hz. Muhammed en adi bir fâsık bile kolay kolay irtikap edemez. Bu isnadın/rivâyetin, bu iftiranın aslı esası yoktur.” Yüksel, bu tespiti yaptıktan sonra çoğu zaman yanlış anlaşılmaya müsait olan söz konusu âyetin meâlini de şöyle verir: "Hem Allah'ın nimetine - Íslam'a- hem senin nimetine - hürriyete- mazhar olan kimseye "Eşini yanında tut Allah'tan kork” diyordun. Fakat Allah'ın açı̆̆a vuracă̆l şeyi -cahiliyet devrinden kalma bir geleneği ortadan kaldırmayl-içinde gizliyordun. Insanlardan çekiniyordun. Oysaki asıl çekinmeye lâyık olan Allah idi. Zeyd o kadından alakasını kesince biz onu seninle evlendirdik ki (bundan böyle) evlatlkları

\footnotetext{
${ }^{37}$ Edip Yüksel'in böyle bir iddiası var. Bk. Yüksel, Günümüz Meselelerine Kur'an'dan Cevaplar, 61.

${ }^{38}$ Yüksel, Günümüz Meselelerine Kur'an'dan Cevaplar, 62-63.

${ }^{39}$ Bk. Ebû Abdullah Muhammed b. Ebû Bekr Kurtubî, el-Câmi' li ahkâmi’l-Kur'ân, thk. Abdullah b. Abdulmuhsin et-Türki (Beyrut: Müessesetü'r-Risâle, 2006), 14/121.
} 
... (akademik, hakemli, indexli, uluslararası dergi)

kadınlarıyla alakalarını kestikleri zaman o kadınlarla evlenmek hususunda mü'minler için bir güçlük olmasin." 40

e. Nesih Meselesindeki Yaklaşımı: Günümüzde de hala tartışma konusu olan neshin varlığı ve kapsamı hususunda tarih boyunca üç ana akımın olduğu söylenebilir:

1. Neshi kabul edip mensuh âyetler konusunda aşırıya kaçanlar.

2. Neshi kabul etmeyenler.

3. Neshi kabul ettiği halde mensuh âyetlerin sayısı hususunda mutedil olanlar. ${ }^{41}$

Molla Sadrettin Yüksel, nesh konusunda geleneğe bağlı olup neshin varlığını kabul etmektedir. Mesela zina suçunu işleyenlere belli durumlarda uygulanan bir ceza olan recm ile ilgili açıklama yaparken şöyle der:

“Herkesin malumu olsun ki İslam'da ölümle neticelenen recm cezası sadece hadisle veya hulefâ-i raşidinin tatbikatıyla değil aksine evvelce nâzil olmuş sonra çok yüce bir hikmete binaen yalnız tilaveti nesh edilmiş bir âyet-i kerime ile sabittir. Hadisle tatbikat ancak o âyetteki hükmün tefsiri mahiyetindedir. Malum mevzuda bu kadar sahih hadisler varid olduktan sonra demek oluyor ki recm, tilaveti mensuh fakat hükmü bâki bir âyetle sabittir. Hadis ve tatbikata gelince o da âyetin tefsiridir. Hz. Ömer ile Ubey b. Ka'b şöyle demişlerdir: “Kur'ân'da indirilen âyetler arasında 'evli erkek ve evli kadın zina yaptıkları zaman onlara kesinlikle recm cezası tatbik edin' âyeti de vardı ve okunuyordu ve sonra tilaveti nesh edildi, kaldırıldı." Fakat bu âyetin hükmü bugüne kadar yürürlüktedir. Tilavetinin nesh edilme hikmeti şu olabilir: Mezkur hükmü toplum içinde yerleştirmek ve böyle bir çirkefe bulaşmayı düşünen evlileri de düşüncelerinden vazgeçirmek için başta bu âyeti kerime okunuyordu. Bu hüküm Müslümanların ruhlarında yerleştikten sonra yine çok önemli başka bir hikmet için de tilaveti neshedildi. Yani lafzının neshindeki gaye bu işin son derece çirkin ve şeni olduğuna işaret etmektir. Sanki Cenab-1 Hak onun tilavetinin kaldırmakla Müslümanlara şöyle bir hitapta bulunuyor: Ey müminler o malum olan fuhuş, çirkinlikte o kadar ileridir ki onu dinlemek ve ondan bahsetmek bile çirkindir. Binaenaleyh siz de kulaklarınızı onu dinlemekten ve dillerinizi de onu söylemekten tenzih edin, temiz tutun". ${ }^{2}$

f. Bilimsel/İlmî Tefsire Bakışı: Kur'ân âyetleri ile bilimsel veriler arasında irtibat kuran ve bazı âyetleri bu veriler 1şı̆̆ında yorumlayan tefsir türüne bilimsel/ilmî tefsir denmektedir. Bu tefsir çeşidinin temel amacı, Kur'ân'ın mucize olduğunu pozitif bilimler açısından da ispatlamaktır.

\footnotetext{
${ }^{40}$ Yüksel, Günümüz Meselelerine Kur'an'dan Cevaplar, 11, 12-13.

${ }^{41}$ Remzi Kaya, “Kur'an-1 Kerim'de Neshi İddia Edilen Âyetler”. Uludağ Üniversitesi İlahiyat Fakültesi Dergisi 7/1 (Ocak 1998), 355; Şükrü Aydın, "Ebû Müslim Muhammed Bahr el-İsfahânî ve Tefsiri”, Yüzüncü Yıl Üniversitesi SBE Dergisi 22 (2012), 134.

${ }^{42}$ Yüksel, Günümüz Meselelerine Kur'an'dan Cevaplar, 35-36.
} 
... (akademik, hakemli, indexli, uluslararası dergi)

Bilimsel tefsir, mazisi çok eskilere dayanmakla birlikte, özellikle yirminci yüzyılda netleşerek ortaya çıktığı ve geliştiği kabul edilen bir ekoldür. ${ }^{43}$

Molla Sadrettin Yüksel, Kur'ân'da fen ve tabiat ilimlerinin öğrenilmesini zımnen teşvik eden birçok âyetin ${ }^{44}$ olduğunu belirtir ve bu âyetleri zikreder. ${ }^{45}$ Daha sonra Yüksel, Kur'ân'ın bilimdışı bir kitap değil, aksine bütün bilimlerin kaynağı olduğunu söyler ve kâinatın genişlemesi, bazı yıldızlarda canlı varlıkların bulunabileceği, her şeyin çift olarak yaratılması, oksijenin yüksek hava tabakasında azalması, atomun parçalanabileceği gibi konular hakkında âyetler zikrederek bu konuları Kur'an çerçevesinde açıklamaya çalışır. ${ }^{46}$

g. Kur'ân'ın Tercümesine Karşı Tutumu: Kur'ân'ın hitabı yalnızca Araplara değil, bütün insanlaradır. Bu yüzden, Kur'ân'ın mesajının Arap olmayan milletler tarafından anlaşılması ve yaşanması amacıyla tercümesi meselesi İslam'ın ilk devirlerinden itibaren gündeme gelen bir konudur. Selmân-1 Fârisî’nin (ö. 36/656) Fâtiha sûresini Farsça'ya çevirmesi ve bunu Hz. Peygamber'e arz ederek onun onayını alması Kur'ân'ın anlamının başka dillere aktarılmasının ilk örneklerinden biri sayılabilir. ${ }^{47} \mathrm{O}$ dönemden günümüze kadar farklı dillere Kur'ân'ın yüzlerce çevirileri yapılmıştır ve yapılmaya devam edilmektedir.

Molla Sadrettin Yüksel de birçok çalışmasında ele aldığı âyetlerin tercümesini yapmıştır. Öyle ki Fâtiha sûresini Arapça olarak tefsir ettiği çalışmasında söz konusu sûrenin âyetlerini de Türkçeye çevirmiştir. Ancak onun meâl ve çevirisi açıklamalı ve daha çok bir tefsir görünümünü arz eden bir tarzdadır. Dolayısıyla Molla Sadrettin'e göre de Kur'ân başka bir dile tercüme edilebilir. Ancak özellikle Tanzimat'tan sonra tefsir ve tercüme faaliyetindeki artış milliyetçilik cereyanıyla ve buna bağlı olarak Kur'ân'1 ana dille okuyup öğrenme gereğine bağlanması Molla Sadrettin'in Kur'ân-1 Kerim'in tercümesi meselesine mesafeli ve ihtiyatla yaklaşmasına neden olmuş ve bu konuda uzunca bir makale de kaleme almıştır. O, makalesinde özetle şunlar söylemektedir:

“Kur’ân’a dair yazılacak hiçbir tercüme Kur’ân sayılmaz. Asırlardan beri İslâm âlimleri tarafından Kur'ân'ı açılamak maksadıyla yazılmış bütün tefsir kitapları bile kâfi gelmiyor. Zira Kur'ân bütün insanlık alemine tevcih edilmiş ezelî ve ebedî bir hitabedir. Zaman ilerledikçe Kur'ân'ın işaretleri tavazzuh eder, meydana çıkar. Her asır ve her nesil Kur'ân'daki hissesini alır, gelecek asır ve nesillerin hisselerine karışamaz. Yani her müfessir ancak kendi asrına göre Kur’ân’a bir tefsir yazabilir. Zamanla

\footnotetext{
${ }^{43}$ Yunus Emre Gördük, "Bilimsel Tefsir ve 20. Yüzyıldaki Meşhur Temsilcileri Perspektifinden Hasan Basri Çantay’ın Açıklamalı Meâli”, Süleyman Demirel Üniversitesi Illahiyat Fakültesi Dergisi /33 (Aralık 2014), $181,182$.

${ }^{44}$ Bk. Hicr 15/19; Fatır 35/27, 28; Zâriyât 51/21; 71/15-16; Tarık 86/5-7.

${ }^{45}$ Bk. Yüksel, İslamî Araştırmlar, 156-161.

${ }^{46}$ Yüksel, İslamî Araştırmlar, 163-171.

${ }^{47}$ Yasin Pişgin, “Kur'an'ın Tercümesi Meselesine Eyüp Sabri Hayırlığlu’nun Bakışı”, Akademik Tarih ve Düşünce Dergisi 6 (Mart 2019), 48.
} 
... (akademik, hakemli, indexli, uluslararasi dergi)

tavazzuh edecek işaretlere nüfuz edemez. Madem kütüphaneleri dolduran yazılmış binlerce tefsir ciltteri

Kur'ân'1 tefsir etmek hususunda kâfi gelmiyor ve Kur'ân'ın genişliğini ihata edemiyor, tek bir cilde sığacak kadar az beşerî bir tercüme mi kâfi gelecek? Kur’ân’ın yerini tutacak? Bu tercüme safsatasını ne mantık kabul eder, ne de ilim! Dahası var nahiv kaidelerine dayanan Arap lisanı yerine Kur'ân’ın meziyet ve nüktelerini başka bir lisan muhafaza edemez. Öyle ise hiç bir tercüme Kur'ân'1 ihata edemez ve onun yerini tutamaz. Eğer İslâm dininin esas kaynağını teşkil eden Kur'ân-1 Kerim Türkçeye çevrilip o tercüme aslın yerine ikame edilse zamanla Kur'ân’ın tercümeleri çoğalıp diğer semavî kitaplar gibi maazallah büyük tahrifata uğrayarak semavîliğini kaybedecektir". ${ }^{48}$

\section{Sonuç}

Kurulduğu günden günümüze Norşin medrese ekolü binlerce âlim/talebe yetiştirmiş olup bu âlimlerden biri de Molla Sadrettin Yüksel'dir. Molla Sadrettin'in ilmi kişiliği incelendiğinde onun Arapça ve İslami ilimlerin hemen hemen her dalında mütehassıs ve söz sahibi birisi olduğu görülecektir. Ancak tedrisatı ve çalışmalarına bakıldığında daha çok tefsir alanına önem verdiği görülmektedir.

Molla Sadrettin Yüksel'in tefsir alanında yaptığı çalışmaları incelendiğinde takip ettiği tefsir metodu ve tefsir anlayışını kısaca şu şekilde ortaya koymak mümkündür.

- Molla Sadrettin, âyetlerin izahı için genellikle Hz. Peygamber'in sünnetine müracaat etmiş ve Resulullah'ın açıklamaları doğrultusunda âyetleri tefsir etmeye çalışmıştır.

- Hemen hemen bütün müfessirler kelime ve cümlelerin anlamları üstünde durdukları gibi, Molla Sadrettin de kelime ve cümlelerin anlamları üstünde durarak lügavî tahlillerde bulunmuştur.

- Molla Sadrettin Yüksel'in tefsir çalışmalarına bakıldığında israiliyyata müracaat etmediği hatta tefsirlerde zikredilen bazı israiliyyat rivâyetlerini çok sert bir dille eleştirdiği görülmektedir.

- Günümüzde bile hala tartışma konusu olan neshin varlığı ve kapsamı hususunda Molla Sadrettin, geleneğe bağlı olup neshi kabul etmektedir.

- Tanzimat'tan sonra tefsir ve tercüme faaliyetindeki artış milliyetçilik cereyanıyla ve buna bağlı olarak Kur'ân'1 ana dille okuyup öğrenme gereğine bağlanması Molla Sadrettin'in Kur'ân-1 Kerim'in tercümesi meselesine mesafeli ve ihtiyatla yaklaşmasına neden olmuştur.

Netice itibarıyla 2004 yılında vefat eden Molla Sadrettin Yüksel'in çalışmaları incelendiğinde farklı alanlarda bir kısmı yayımlanmış bir kısmı da hala yayımlanmamış Türkçe ve Arapça irili ufaklı

48 Yüksel, İslamî Araştırmalar, 112-120. 
... (akademik, hakemli, indexli, uluslararası dergi)

olmak üzere 33 adet olduğu görülecektir. Yüksel'in bu çalışmalarının okuyucuların istifadesine sunmak için özellikle genç akademisyenlerin bu konuda üzerine düşen vazifeyi icra etmeleri büyük bir önem arz etmektedir.

\section{Kaynakça}

Altın, Mehmet (2020). "Mühmel Tefsirler Üzerine Bir Değerlendirme”. Diyanet İlmi Dergi 56/3, 653-676.

Aydın, Şükrü (2012). “Ebû Müslim Muhammed Bahr el-İsfahânî ve Tefsiri”. Yüzüncü Yıl Üniversitesi SBE Dergisi 22, 133-164.

Baz, İbrahim (2014). “Osmanlı'dan Cumhuriyete Norşin Dergâhı ve Şeyh Abdurrahman-1 Tâğ̂̀”. Tasavvuf /34, 75-110.

Çakır, Mehmet Saki (2017). “Şeyh Abdurrahman Tâğî ve Norşin Tekkesi’nden Yayılan Kollar”. İhya Uluslararası İslam Araştırmaları Dergisi 3/2, 26-53.

Çelik, İmran (2013). “Geleneği Olan Medreseler ve Tarihi Kökenleri (Tillo Ve Nurşin Örnekleri)”. Medrese Geleneği ve Modernleşme Sürecinde Medreseler Uluslararası Sempozyum. ed. Fikret Gedikli. 1/105-125. Muş: Muş Alparslan Üniversitesi Yayınları.

Çiçek, M. Halil (2009). Şark Medreselerinin Serencamı. İstanbul: Beyan Yayınları.

Elçi, Mehmet Sadık (2010). Son Dönem Âlimlerden Molla Sadrettin Yüksel ve Fetvâları. Diyarbakır: Dicle Üniversitesi, Sosyal Bilimler Enstitüsü, Yüksek Lisans Tezi.

Ermiş, Metin (2019). Hâlidî Medrese Geleneği ve Norşin Medresesi. Van: Van Yüzüncü Y1l Üniversitesi, Sosyal Bilimler Enstitüsü, Yüksek Lisans Tezi.

Gördük, Yunus Emre (2014). “Bilimsel Tefsir ve 20. Yüzyıldaki Meşhur Temsilcileri Perspektifinden Hasan Basri Çantay’ın Açıklamalı Meâli”. Süleyman Demirel Üniversitesi Ilahiyat Fakültesi Dergisi /33, 181-214.

İnbaşı, Mehmet - Demirtaş, Mehmet (ed.) (2019). Tarihî ve Kültürel Yönleriyle Bitlis. 2 Cilt. Ankara: Kalkan Matbaacilık.

Kaya, Remzi (1998). “Kur'an-1 Kerim'de Neshi İddia Edilen Âyetler”. Uludă̆ Üniversitesi İlahiyat Fakültesi Dergisi 7/1, 353-371.

Korkusuz, Şefik (2010). Nehrî'den Hazne'ye Meşayih-i Nakşibendî. İstanbul: Pak Ajans Yayıncılık. Kurtubî, Ebû Abdullah Muhammed b. Ebû Bekr (2006). el-Câmi 'li ahkâmi’l-Kur'ân. thk. Abdullah b. Abdulmuhsin et-Türki. 24 Cilt. Beyrut: Müessesetü'r-Risâle.

Mutlu, Abdülgani (2021). Kişisel Görüşme (10.05.2021).

Nursî, Said (2014). İşârâtü’l-i ‘câz. Ankara: DİB Yayınları. 
... (akademik, hakemli, indexli, uluslararası dergi)

Nursî, Said (1995). Mesnevî-i Nuriye. İstanbul: Envar Neşriyat.

Pişgin, Yasin (2019). “Kur'ân'ın Tercümesi Meselesine Eyüp Sabri Hayırlığlu'nun Bakışı”. Akademik Tarih ve Düşünce Dergisi 6, 48-68.

Tirmizî, Ebû Îsâ Muhammed b. Îsâ b. Sevre (2000). el-Câmi 'u's-sahîh. thk. Muhammed Nasruddin el-Elbânî. 3 Cilt. Riyad: Mektebetü'l-Maarif.

Ürek, İzzettin (2020). Günümüz Bitlis Medreselerinde Mantık Eğitimi (Norşin Medreseleri Örneği). Diyarbakır: Dicle Üniversitesi, Sosyal Bilimler Enstitüsü, Yüksek Lisans Tezi.

Y1lmaz, Edip (2021). Kişisel Görüşme (15.05.2021).

Yüksel, Müfid (2005). “Sadrettin Yüksel Hocanın Ardından”. Tezkire 141, 202-209.

Yüksel, Müfid (2005). “Sadreddin Yüksel”. Hadis Tetkikleri Dergisi 3/1, 195-198.

Yüksel, Sadrettin (1998). Günümüz Meselelerine Kur'ân'dan Cevaplar. İstanbul: Madve Yayınlar1.

Yüksel, Sadrettin (1992). İslamî Araştırmalar. İstanbul: Madve Yayınları. 


\section{EKLER} (akademik, hakemli, indexli, uluslararası dergi)

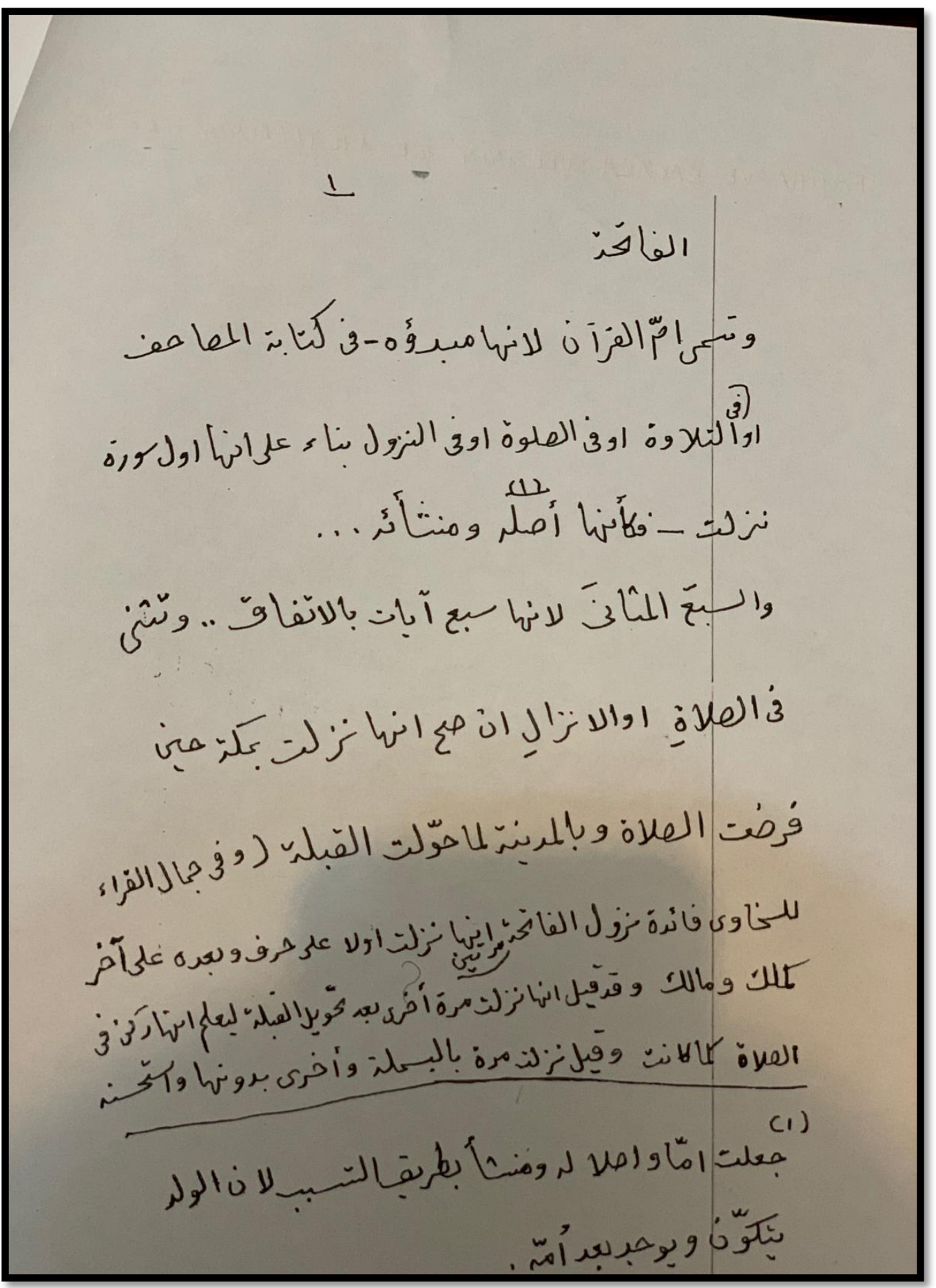

Ek 1: Molla Sadrettin Yüksel'in müsvedde halinde olan Fatiha Sûresi Meâl ve Tefsiri'nin ilk sayfasi. 


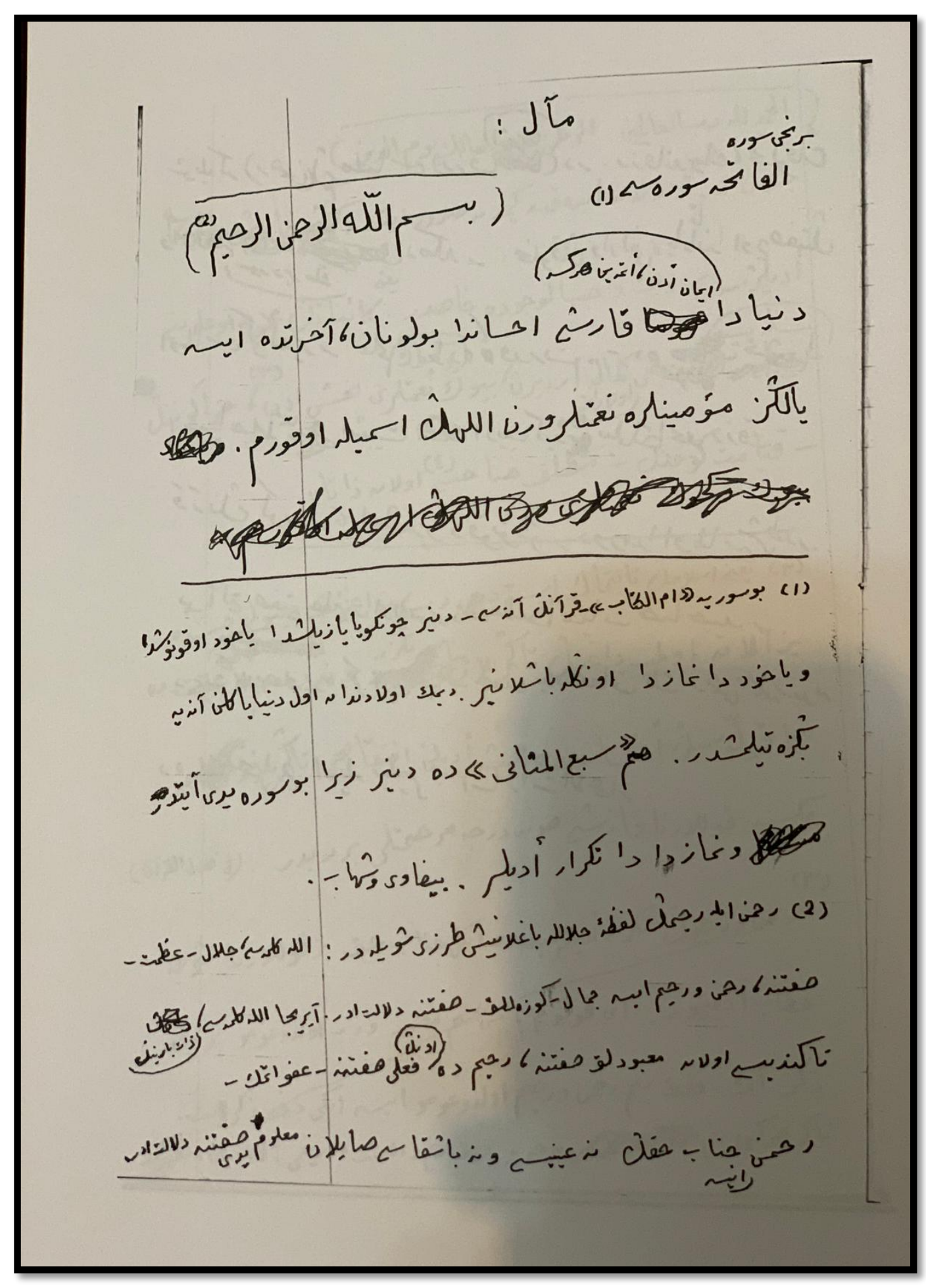

Ek 2: Molla Sadrettin Yüksel'in müsvedde halinde olan Fatiha Sûresi Meâl ve Tefsiri'nin Türkçe meâl kısmının ilk sayfası. 


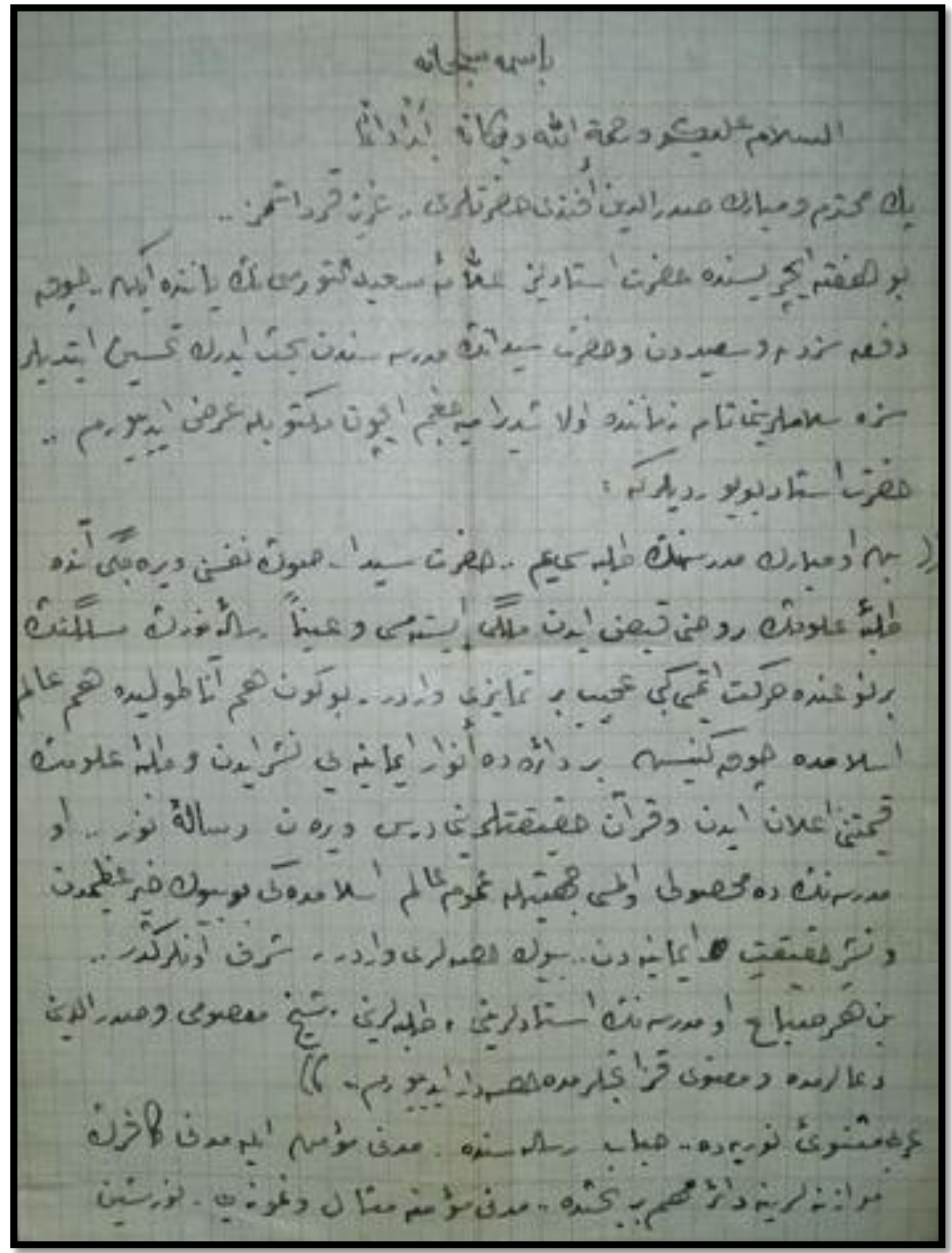

Ek 3: Bediüzzaman Said Nursî’nin talebesi Mustafa Sungur aracılığı ile Molla Sadreddin Yüksel'e gönderdiği mektubu. 